\title{
A SIMPLIFIED LIFE-CYCLE COST METHODOLOGY FOR ANALYSIS OF LAMPS AND BALLASTS IN FEDERAL BUILDINGS (1992 Edition)
}

Stephen R. Petersen

Computing and Applied Mathematics Laboratory

Office of Applied Economics

U.S. Department of Commerce

Technology Administration

National Institute of Standards and Technology $-\mathrm{OC}$

Faithersburg, MD 20899
Prepared for:

U.S. Department of Energy

Federal Energy Management Program 1000 Independence Avenue, S.W.

Washington, D.C. 20585

100

.056

4784

1992

C. 2 



\section{A SIMPLIFIED LIFE-CYCLE COST METHODOLOGY FOR ANALYSIS OF LAMPS AND BALLASTS IN FEDERAL BUILDINGS (1992 Edition)}

Stephen R. Petersen

February 1992

Computing and Applied Mathematics Laboratory Office of Applied Economics

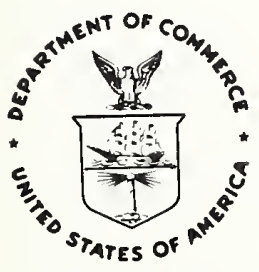

\section{U.S. Department of Commerce}

Rockwell A. Schnabel, Acting Secretary Technology Administration

Robert M. White, Under Secretary for Technology National Institute of Standards and Technology John W. Lyons, Director

Prepared for:

U.S. Department of Energy Federal Energy Management Program 1000 Independence Avenue, S.W. Washington, D.C. 20585 



\section{Abstract}

A simplified life-cycle cost (LCC) methodology for the economic analysis of lighting system components (lamps and ballasts) is presented. The use of LCC analysis encourages purchasers and installers of lighting system components to select the most cost-effective combination of lamps and ballasts for new or replacement applications. The methodology is consistent with the life-cycle cost requirements for energy conservation investments in Federal buildings outlined in NBS Handbook 135, Life-Cycle Costing Manual for the Federal Energy Management Program. The methodology uses annual-value life-cycle costs to permit direct comparison of components that have different lives. Look-up tables of annual-value factors are provided to minimize calculation requirements. Examples are provided for selection of both individual components and combinations of components. Replacement of functioning components with new, higher efficiency components is also examined. This is the FY 92 version of this report, using the updated discount rate and DOE energy price projections. 


\section{Preface}

This methodology was prepared at the request of Dean K. DeVine of the Federal Energy Management Program (FEMP) in support of the Federal relamping initiative. The methodology is consistent with other FEMP life-cycle cost criteria as well as Handbook 135, Life-Cycle Costing Manual for the Federal Energy Management Program; the 1992 Supplement to Handbook 135; and the Building Life-Cycle Cost (BLCC) computer program, version 3.1 (FY 92). This report is an updated version of the original 1991 report, with revised tables and examples to reflect the DOE discount rate and projections of energy prices for 1992. 


\section{Acknowledgments}

The author would like to acknowledge the timely review of this report by Sieglinde Fuller and Stephen Treado of NIST and Dean DeVine of DOE. In addition, thanks are due to Laurene Linsenmayer for her assistance in preparing the final manuscript. 


\section{CONTENTS}

Page

Abstract $\ldots \ldots \ldots \ldots \ldots \ldots \ldots \ldots \ldots \ldots \ldots \ldots \ldots \ldots \ldots \ldots \ldots$ iii

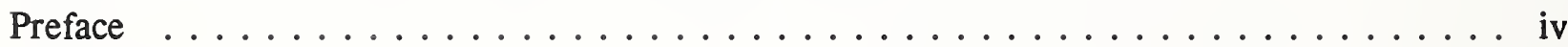

Acknowledgments $\ldots \ldots \ldots \ldots \ldots \ldots \ldots \ldots \ldots \ldots \ldots \ldots \ldots$

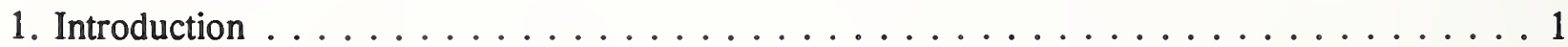

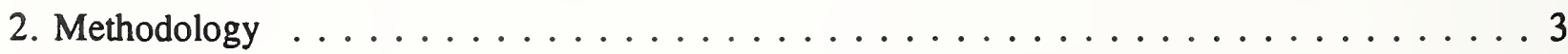

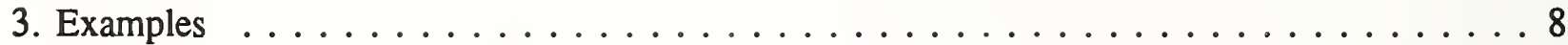

4. Replacement of Functioning Components $\ldots \ldots \ldots \ldots \ldots \ldots \ldots \ldots$

Appendix A. Computational methods for tables $1-4 \ldots \ldots \ldots \ldots \ldots \ldots$

Appendix B. Limitations on the use of annual-value LCC for comparing investments with different lives $\ldots \ldots \ldots \ldots \ldots 14$

\section{TABLES}

Table 1. Annual-value factors for installed lamp costs (F1) when evaluated over their own life $\ldots \ldots \ldots \ldots \ldots \ldots \ldots$

Table 2. Annual-value factors for installed lamp costs (F2) when evaluated over the life of the ballast . . . . . . . . . . 7

Table 3. Annual-value factors for installed ballast costs $(\mathrm{F} 3) \ldots \ldots \ldots \ldots$

Table 4. Annual-value factors for first-year electricity costs (F4) $\ldots \ldots \ldots \ldots \ldots 7$ 


\section{Introduction}

The purpose of this report is to provide a simplified methodology with look-up tables which can be used to determine the most cost-effective lamps or lamp/ballast combinations for lighting fixtures in Federal buildings. The methodology is primarily applicable to existing lighting fixtures, but can be used for new fixtures as well if the lamps or lamp/ballast components can be specified before installation. It can also be used to determine whether or not a functioning lamp or ballast can be economically replaced with a component that consumes less energy.

The methodology provides an estimate of the annual-value cost of purchasing, installing, and operating a lamp or lamp/ballast combination over its expected life in a specific operating environment. An annual-value cost is a uniform annual cost extending over the life of a system, which, when discounted to present value, is equivalent to the life-cycle cost of that system. Alternative lamps or lamp/ballast combinations can be directly compared based on their annual-value cost. The alternative with the lowest annual-value cost is considered to be the most cost effective for that environment. The wattage requirements of each alternative lamp/ballast combination, the operating hours per year, current local $\mathrm{kWh}$ costs and $\mathrm{kW}$ demand charges (if any), the life expectancy of the alternative lamps and ballasts, and their installed costs are needed to use this methodology.

This methodology is intended primarily for use by facilities managers who wish to evaluate a relatively small number of alternative energy-conserving lighting system components without the use of a computer program. It is consistent with the life-cycle cost procedures detailed in NBS Handbook 135, Life-Cycle Costing Manual for the Federal Energy Management Program ${ }^{1}$ and American Society for Testing and Materials Standard E-917, "Standard Practice for Measuring LifeCycle Costs of Buildings and Building Systems². A 4.\% (real) discount rate and 1992 projections of future increases in electricity costs from the U.S. Department of Energy/Energy Information Administration $^{3}$ are incorporated into the annual-value factors used in this report. However, all costs are converted to their annual-value equivalents in order to permit the direct comparison of components with different expected lives. This eliminates the need to determine a common study period for all alternatives, which is required if the life-cycle costs of all alternatives are to be compared directly.

${ }^{1}$ Ruegg, Rosalie T., Life-Cycle Costing Manual for the Federal Energy Management Program, NBS Handbook 135, National Bureau of Standards (now National Institute of Standards and Technology), Gaithersburg, MD 20899, Revised 1987.

${ }^{2}$ Annual Book of ASTM Standards (1990), Section 4, Construction, Volume 04.07 Building Constructions, American Society for Testing and Materials, Philadelphia, PA 19103, 1990.

${ }^{3}$ Lippiatt, Barbara C., Energy Prices and Discount Factors for Life-Cycle Cost Analysis 1992, NISTIR 85-3273-6 (Rev. 10/91), National Institute of Standards and Technology, Gaithersburg, MD 20899, October 1991. 
Appendix A contains the equations used to calculate the annual-value factors provided in this report. Appendix B addresses limitations on the use of annual-value life-cycle costs for comparing investments with different lives. Reading the appendices is not required to use this simplified methodology.

It is assumed that all components selected for evaluation are technically compatible and capable of providing the required intensity, quality, and distribution of light throughout their expected life. This methodology does not address the degradation in useful light output over time from lighting fixtures due to dust accumulation and component deterioration. In general, such degradation does not increase energy consumption directly, but frequently causes lighting systems to be oversized at the time of installation in order to compensate for this loss. It should be noted that a program of strategic maintenance and cleaning can permit fewer fixtures to be installed initially, conserving both capital and energy.

This simplified methodology does not consider the potential value of the heat output from lighting systems during heating hours or the potential cost of removing this heat during cooling hours. A whole-building energy analysis is generally needed to evaluate the contribution of these factors to the benefits from more efficient lighting components. However, recognition that these additional benefits are often attributable to high efficiency lighting systems can be useful in choosing among components with otherwise similar annual-value costs. 


\section{Methodology}

This simplified methodology helps facilities managers to determine the most cost-effective lamps, ballast, or lamp/ballast combination for installation in a new or existing lighting fixture in a specified operating environment. This methodology has seven steps and uses four tables of annual-value factors. These tables are shown on page 7. Its use requires no more than a four-function hand calculator.

Use the general methodology presented in this section when the existing components, if any, must be replaced now. See section 4 for cases where new, higher-efficiency components are to be evaluated as replacements for existing and functioning lower-efficiency components.

Step 1:

Determine the available lamps, ballasts or lamp/ballast combinations appropriate and available for use in the lighting fixture of interest, along with their installed cost and expected life. For each lamp, ballast, or combination to be evaluated, determine the watt (W) input for the lighting fixture from an appropriate handbook or table. If the fixture requires a ballast, both lamp and ballast characteristics must be considered in determining the wattage input of the fixture, even if only lamps or only ballasts are being replaced. In general, components which have a higher installed cost but lower energy requirements should be compared with components having a lower installed cost but higher energy requirements.

Notes:

(1) If the expected life of a lamp or ballast is specified in hours, convert to years using the operating hours per year for the fixture of interest. (For example, a 2000-hour lamp using 1000 per year has a life of two years.)

(2) If the life of a lamp is less than one year, divide its installed cost by its life in years to estimate a yearly cost. (For example, a $\$ 1.00$ lamp with a six-month (0.5 years) life would have a yearly cost of $\$ 2.00$.)

(3) If lamps are generally replaced as they fail (spot replacement), then the installed lamp cost should be based on spot replacement procurement and labor costs. If all lamps are instead replaced after a given percentage fail (group replacement), then the installed lamp cost should be based on group replacement procurement and labor costs. In the latter case, use the time of expected group replacement for the expected lamp life. (As a default value, use $80 \%$ of the expected lamp life.) In general, spot replacement as a maintenance policy is significantly more costly than group replacement.

(4) If you expect all the lamps being evaluated to have the same expected life and installation cost, you can simplify the analysis by excluding installation costs from the cost of the lamps. Similarly, if you expect all the ballasts being compared to have the same expected life and installation cost, you can exclude their installation cost from the cost of the ballast. If alternative lamp/ballast combinations are being evaluated, it is assumed that lamp replacement costs throughout the life of the ballast are the same as their initial installed cost (in constant dollars). 
Step 2:

Determine the annual-value installed cost of each component, using the appropriate factors from tables 1,2 , or 3 , as described below. If a non-integer life greater than one year is used, interpolate the factors for the years immediately below and above the life to find the desired factor.

A. If evaluating alternative lamps only, find the annual-value factor for installed lamps costs (F1) from table 1, based on the expected life of the lamp. Multiply the installed lamp cost (ILC) by F1 to find the annual-value lamp cost, AVLC:

$$
\mathrm{AVLC}=\mathrm{ILC} \times \mathrm{F} 1
$$

B. If evaluating alternative lamp/ballast combinations for installation at the same time, find the annual-value factor for installed lamp costs (F2) from table 2, based on the expected lives of both the lamp (column) and the ballast (row). Multiply the installed lamp cost (ILC) by F2 to find the annual-value lamp cost, AVLC:

$$
\mathrm{AVLC}=\mathrm{ILC} \times \mathrm{F} 2
$$

The annualization factor in table 2 includes the replacement costs of the lamps over the life of the ballast, assuming the same installed cost each time (in constant dollars). The lamps are assumed to be scrapped along with the ballast at the end of the ballast life.

C. If evaluating alternative ballasts or alternative lamp/ballast combinations, find the annualvalue factor for installed ballast costs (F3) from table 3, based on the life of the ballast. Multiply the installed ballast cost (IBC) by F3 to find the annual-value ballast cost, AVBC:

$$
\mathrm{AVBC}=\mathrm{IBC} \times \mathrm{F} 3
$$

For lamp/ballast combinations, installing both lamps and ballast at the same time usually reduces labor costs relative to installing these components separately. In these cases, subtract the labor costs savings (LCS) from the installed cost of the ballast when computing AVBC:

$$
\mathrm{AVBC}=(\mathrm{IBC}-\mathrm{LCS}) \times \mathrm{F} 3
$$

\section{Step 3:}

Determine the approximate annual $\mathrm{kWh}$ energy consumption $(\mathrm{kWh} / \mathrm{y})$ of the lighting fixture for each alternative lamp type, ballast type, or lamp/ballast combination, based on its wattage requirements $(W)$ and the expected number of operating hours per year $(h / y)$ :

$$
\mathrm{kWh} / \mathrm{y}=\mathrm{Wx} \mathrm{h} / \mathrm{y} / 1000
$$


Step 4:

Determine the annual electricity cost (AEC) per fixture for each alternative lamp type, ballast type, or lamp/ballast combination, based on the current cost of electricity per $\mathrm{kWh}(\$ / \mathrm{kWh})$ and the yearly demand charge per $\mathrm{kW}$ of peak demand $(\$ / \mathrm{kW})$ at the building site.

If $\mathrm{kW}$ demand charges are not included in the electricity rate schedule, or these lights are not expected to be on during peak demand hours, use:

$$
\mathrm{AEC}=\mathrm{kWh} / \mathrm{y} \times \$ / \mathrm{kWh}
$$

If $\mathrm{kW}$ demand charges are included in the electricity rate schedule, and these lights are expected to be on during peak demand hours, use:

$$
\mathrm{AEC}=\mathrm{kWh} / \mathrm{y} \times \$ / \mathrm{kWh}+\mathrm{kW} \times \$ / \mathrm{kW} / 1000
$$

Notes:

(1) If a declining block rate schedule is applicable, use the cost per $\mathrm{kWh}$ for the block that corresponds to the typical monthly level of $\mathrm{kWh}$ usage for the building or site. If summer $\mathrm{kWh}$ rates are significantly different from winter $\mathrm{kWh}$ rates, weight the summer and winter rates by the ratio of months in each schedule to the total months in the year and add them together. For example, 7 months at $\$ 0.05$ and 5 months at $\$ 0.10$ yield a weighted average cost of:

$$
7 / 12 \times \$ 0.05 / \mathrm{kWh}+5 / 12 \times \$ 0.10 / \mathrm{kWh}=\$ 0.0708 / \mathrm{kWh} \text {. }
$$

(2) Demand charges are typically levied month to month over the year, based on peak $\mathrm{kW}$ usage metered at a particular point in time during the month or year. Monthly demand charges per $\mathrm{kW}$ of peak demand must be aggregated over the year to arrive at a yearly demand charge. For example, if a demand charge of $\$ 1.00 / \mathrm{kW}$ is charged each month of the year based on the highest $\mathrm{kW}$ usage of the building any time during the year, the yearly demand charge is $\$ 12.00 / \mathrm{kW}(\$ 1.00 / \mathrm{kW} \times 12)$. Demand schedules are often complicated and require careful analysis to arrive at an appropriate yearly demand charge.

\section{Step 5:}

Determine the appropriate annual-value factor for electricity costs (F4) from table 4 as follows: For comparing lamps alone, use the factor corresponding to the life of the shortest-lived of the alternative lamps. For comparing ballasts alone or in combination with lamps, use the factor corresponding to the life of the shortest-lived ballast. Multiply the AEC by the annual-value factor to get the annual-value energy cost (AVEC).

$$
\mathrm{AVEC}=\mathrm{AEC} \times \mathrm{F} 4
$$


Step 6:

Determine the total annual-value cost (TAVC) per fixture for each alternative lamp, ballast, or combination:

A. If evaluating lamps only, find TAVC for each alternative by summing the annual-value lamp cost (AVLC) and annual-value electricity cost (AVEC):

$$
\text { TAVC }=\text { AVLC }+ \text { AVEC }
$$

B. If evaluating lamp/ballast combinations, find the TAVC for each alternative combination by summing the annual-value lamp cost (AVLC), annual-value ballast cost (AVBC), and annualvalue electricity cost (AVEC):

$$
\mathrm{TAVC}=\mathrm{AVLC}+\mathrm{AVBC}+\mathrm{AVEC}
$$

C. If evaluating ballasts only, find the TAVC for each alternative by summing the annual-value ballast cost (AVBC) and the annual-value electricity cost (AVEC):

$$
\text { TAVC }=\text { AVBC }+ \text { AVEC }
$$

Step 7:

Determine the lamp, ballast or lamp/ballast combination with the lowest TAVC per fixture. This is the most cost-effective component (or combination of components) in this operating environment. The reduction (increase) in TAVC due to the use of higher efficiency components relative to lower efficiency components is the annual-value net savings (loss) attributable to the higher efficiency components. 
Annual-value factors for economic analysis of lamps and ballasts (All factors based on a $4.6 \%$ real discount rate in 1992)

Table 1. Annual-value factors for installed lamp costs (F1) when evaluated over their own life

\begin{tabular}{cccccccccc}
\multicolumn{11}{c}{ Expected lamp life (years) } \\
1 & 2 & 3 & 4 & 5 & 6 & 7 & 8 & 9 & 10 \\
\hline 1.05 & 0.54 & 0.37 & 0.28 & 0.23 & 0.20 & 0.17 & 0.15 & 0.14 & 0.13
\end{tabular}

Table 2. Annual-value factors for installed lamp costs (F2) when evaluated over the life of the ballast ${ }^{4}$

\begin{tabular}{|c|c|c|c|c|c|c|c|c|c|c|c|}
\hline & & & & & ted & $p$ & $\langle y$ & & & & \\
\hline & & 1 & 2 & 3 & 4 & 5 & 6 & 7 & 8 & 9 & 10 \\
\hline & 10 & $\overline{1.05}$ & 0.53 & 0.42 & 0.32 & 0.23 & 0.22 & 0.22 & 0.22 & 0.21 & 0.21 \\
\hline & 11 & 1.0 & 0.57 & 0.39 & 0.30 & 0.29 & 0.21 & 0.20 & 0.20 & 0.20 & 0.19 \\
\hline & 12 & 1. & 0. & 0.36 & 0.28 & 0.27 & 0.19 & 0.19 & 0.19 & 0.18 & 0.18 \\
\hline & 13 & 1. & 0. & 0.40 & 0.32 & 0.25 & 0.24 & 0.18 & 0.18 & 0.17 & 0.17 \\
\hline & 14 & & & 0 & & 0.24 & 0.23 & 0.17 & 0.17 & .16 & 0 \\
\hline & 15 & 1. & 0.5 & 0.36 & 0.29 & 0.23 & 0.22 & 0.21 & 0.16 & 0. & 0. \\
\hline 1180 & 16 & 1. & 0.5 & 0.39 & 0.28 & 0.26 & 0.21 & 0.20 & 0. & 0. & 0 \\
\hline lif & 17 & 1. & 0. & 0.38 & 0.31 & 0.25 & 0.20 & 0.19 & 0.19 & 0.14 & 0.14 \\
\hline & 18 & 1. & 0. & 0.36 & 0.30 & 0.24 & 0.19 & 0.19 & 0.18 & 0.14 & 0.14 \\
\hline & 19 & 1. & 0. & 0.39 & 0.29 & 0.24 & 0.22 & 0.18 & 0.17 & 0.17 & 0.13 \\
\hline & & & & 0.3 & 0.28 & 0.23 & 0.22 & 0.18 & 0.17 & 0.16 & 0.13 \\
\hline
\end{tabular}

Table 3. Annual-value factors for installed ballast costs (F3)

\begin{tabular}{ccccccccccc}
10 & 11 & 12 & 13 & 14 & 15 & 16 & 17 & 18 & 19 & 20 \\
\hline 0.13 & 0.12 & 0.11 & 0.10 & 0.10 & 0.09 & 0.09 & 0.09 & 0.08 & 0.08 & 0.08
\end{tabular}

Table 4. Annual-value factors for first-year electricity costs (F4)

\begin{tabular}{|c|c|c|c|c|}
\hline \multirow{3}{*}{$\begin{array}{c}\text { Life } \\
\text { (Yearc) }\end{array}$} & \multicolumn{4}{|c|}{ DOE region } \\
\hline & 1 & 2 & 3 & 4 \\
\hline & Northeast & Midwest & South & West \\
\hline 1 & 1.00 & 0.98 & 1.00 & 0.99 \\
\hline 2 & 1.00 & 0.98 & 1.02 & 0.99 \\
\hline 3 & 0.99 & 0.99 & 1.01 & 0.99 \\
\hline 4 & 0.98 & 0.98 & 1.01 & 0.99 \\
\hline 5 & 0.98 & 0.97 & 1.00 & 0.99 \\
\hline 6 & 0.97 & 0.96 & 0.99 & 0.98 \\
\hline 7 & 0.96 & 0.95 & 0.99 & 0.98 \\
\hline 8 & 0.96 & 0.95 & 0.99 & 0.98 \\
\hline 9 & 0.96 & 0.94 & 0.99 & 0.98 \\
\hline 10 & 0.96 & 0.94 & 0.99 & 0.98 \\
\hline 11 & 0.96 & 0.94 & 0.99 & 0.98 \\
\hline 12 & 0.95 & 0.94 & 0.98 & 0.98 \\
\hline 13 & 0.95 & 0.93 & 0.99 & 0.98 \\
\hline 14 & 0.95 & 0.93 & 0.99 & 0.9 \\
\hline 15 & 0.95 & 0.93 & 0.99 & 0.99 \\
\hline 16 & 0.95 & 0.93 & 0.99 & 0.99 \\
\hline 17 & 0.95 & 0.93 & 0.99 & 0.99 \\
\hline 18 & 0. & 0.93 & 0.99 & 0.99 \\
\hline 19 & 0. & 0.93 & 0.99 & 1.00 \\
\hline 20 & 0.95 & 0.94 & 0.99 & 1.00 \\
\hline
\end{tabular}
life.

${ }^{4}$ Includes replacement cost of lamps up to the end of the designated ballast 


\section{Examples}

This section provides examples of the use of the simplified LCC methodology for evaluating lamps only, ballasts only, and lamp/ballast combinations. In each of these examples, the most cost effective lamp, ballast, or combination for the fixture of interest is to be identified. For the analysis of replacing functioning components with more efficient or lower wattage components, see section 4 .

Basic assumptions for all examples:

Fixture operating hours per year $=3000$

Average cost per $\mathrm{kWh}=\$ 0.08$; no demand charges

DOE region $=4$ (West)

Two lamps and one ballast per fixture

Life of lamp $=5$ years (same for both higher efficiency and lower efficiency types)

Cost of lower efficiency lamp $=\$ 2.00$

Cost of higher efficiency lamp $=\$ 2.50$

Installation costs of lamps $=\$ 5.00$ per fixture

Life of ballast $=15$ years for lower efficiency units, 20 years for higher efficiency units

Cost of lower efficiency ballast $=\$ 25.00$

Cost of higher efficiency ballast $=\$ 30.00$

Installation costs of ballast $=\$ 7.50$ per fixture (with or without lamp

replacement at the same time)

Example 1. Lamps only:

Lower efficiency lamps:

Installed Lamp Cost (ILC) $=2 \times \$ 2.00+\$ 5.00=\$ 9.00$

Annual-value installed cost (AVLC) $=\$ 9.00 \times 0.23=\$ 2.07$ (F1 based on 5-year life)

Total $\mathrm{W}$ requirement $=130 \mathrm{~W}$ per fixture

$\mathrm{kWh} / \mathrm{y}=130 \mathrm{~W} \times 3000 \mathrm{~h} / \mathrm{y} / 1000 \mathrm{~W} / \mathrm{kW}=390$

Annual Electricity Cost (AEC) $=390 \mathrm{kWh} / \mathrm{y} \times \$ 0.08 / \mathrm{kWh}=\$ 31.20$

Annual-Value Electricity Cost (AVEC) $=\$ 31.20 \times 0.99=\$ 30.89$ (F4 based on 5-year life, West)

Total Annual-value Cost $($ TAVC $)=\$ 2.07+\$ 30.89=\$ 32.96$

Higher efficiency lamps:

Installed Lamp Cost (ILC) $=2 \times \$ 2.50+\$ 5.00=\$ 10.00$

Annual-value installed cost (AVLC) $=\$ 10.00 \times 0.23=\$ 2.30$ (F1 based on 5-year life)

Total $\mathrm{W}$ requirement $=120 \mathrm{~W}$ per fixture

$\mathrm{kWh} / \mathrm{y}=120 \mathrm{~W} \times 3000 \mathrm{~h} / \mathrm{y} / 1000 \mathrm{~W} / \mathrm{kW}=360 \mathrm{kWh} / \mathrm{y}$

Annual Electricity Cost (AEC) $=360 \mathrm{kWh} / \mathrm{y} \times \$ 0.08 / \mathrm{kWh}=\$ 28.80$

Annual-Value Electricity Cost (AVEC) $=\$ 28.80 \times 0.99=\$ 28.51$ (F4 based on 5-year life, West)

Total Annual-value Cost $($ TAVC $)=\$ 2.30+\$ 28.51=\$ 30.81$

Annual-value net savings for higher efficiency lamps $=\$ 32.96-\$ 30.81=\$ 2.15$

Conclusion: lower wattage lamps have annual-value net savings of $\$ 2.15$ per fixture relative to the higher wattage lamps and therefore are the more cost-effective choice. 
Example 2. Ballast only:

Lower efficiency ballast (15-year life):

Installed Ballast Cost (IBC) $=\$ 25.00+\$ 7.50=\$ 32.50$

Annual-value installed cost (AVBC) $=\$ 32.50 \times 0.09=\$ 2.93$ (F3 based on 15-year life)

Total $\mathrm{W}$ requirement $=120 \mathrm{~W}$ per fixture

$\mathrm{kWh} / \mathrm{y}=120 \mathrm{~W} \times 3000 \mathrm{~h} / \mathrm{y} / 1000 \mathrm{~W} / \mathrm{kW}=360 \mathrm{kWh} / \mathrm{y}$

$\mathrm{AEC}=360 \mathrm{kWh} / \mathrm{y} \times \$ 0.08 / \mathrm{kWh}=\$ 28.80$

AVEC $=\$ 28.80 \times 0.99=\$ 28.51$ (F4 based on 15-year life, West)

$\mathrm{TAVC}=\$ 2.93+\$ 28.51=\$ 31.44$

Higher efficiency ballast (20-year life):

Installed Ballast Cost (IBC) $=\$ 30.00+\$ 7.50=\$ 37.50$

Annual-value installed cost (AVBC) $=\$ 37.50 \times 0.09=\$ 3.38$ (F3 based on 20-year life)

Total $\mathrm{W}$ requirement $=110 \mathrm{~W}$ per fixture

$\mathrm{kWh} / \mathrm{y}=110 \mathrm{~W} \times 3000 \mathrm{~h} / \mathrm{y} / 1000 \mathrm{~W} / \mathrm{kW}=330 \mathrm{kWh} / \mathrm{y}$

$\mathrm{AEC}=330 \mathrm{kWh} / \mathrm{y} \times \$ 0.08 / \mathrm{kWh}=\$ 26.40$

AVEC $=\$ 26.40 \times 0.99=26.14$ (Note that same F4 used for both ballasts, based on 15-year life, West)

TAVC $=\$ 3.38+\$ 26.14=\$ 29.52$

Annual-value net savings for high efficiency ballast $=\$ 31.44-\$ 29.52=\$ 1.92$

Conclusion: higher efficiency ballast has annual-value net savings of $\$ 1.92$ per fixture relative to the lower efficiency ballast and is therefore the more cost-effective choice. 
Example 3. Lamp/ballast combinations:

Lower efficiency lamp/ballast combination (15-year ballast life):

ILC $=2 \times \$ 2.00+\$ 5.00=\$ 9.00$

Annual-value installed lamp cost $=\$ 9.00 \times 0.23=\$ 2.07$ ( $\mathrm{F} 2$ based on 15 -year ballast life and 5-year lamp life

$\mathrm{IBC}=\$ 25.00+\$ 7.50=\$ 32.50$

Labor cost savings (LCS) $=\$ 5.00$ (from simultaneous installation of ballast and lamps)

Annual-value installed ballast cost $=(\$ 32.50-\$ 5.00) \times 0.09=\$ 2.48$ (F3 based on 15-year ballast life)

Total $\mathrm{W}$ requirement $=130 \mathrm{~W}$ per fixture

$\mathrm{kWh} / \mathrm{y}=130 \mathrm{~W} \times 3000 \mathrm{~h} / \mathrm{y} / 1000 \mathrm{~W} / \mathrm{kW}=390 \mathrm{kWh} / \mathrm{y}$

$\mathrm{AEC}=390 \mathrm{kWh} \times \$ 0.08 / \mathrm{kWh}=\$ 31.20 / \mathrm{y}$

AVEC $=\$ 31.20 \times 0.99=\$ 30.89$ (F4 based on 15-year life of ballast)

$\mathrm{TAVC}=\$ 2.07+\$ 2.48+\$ 30.89=\$ 35.44$

Higher efficiency lamp/ballast combination (20-year ballast life):

ILC $=2 \times \$ 2.50+\$ 5.00=\$ 10.00$

Annual-value installed lamp cost $=\$ 10.00 \times 0.23=\$ 2.30$ (F2 based on 15-year ballast

life and 5-year lamp life

IBC $=\$ 30.00+\$ 7.50-\$ 5.00=\$ 32.50$

Annual-value installed ballast cost $=\$ 32.50 \times 0.08=\$ 2.60$ ( $\mathrm{F} 3$ based on 15-year ballast life)

Total $\mathrm{W}$ requirement $=110 \mathrm{~W}$ per fixture

$\mathrm{kWh} / \mathrm{y}=110 \mathrm{~W} \times 3000 \mathrm{~h} / \mathrm{y} / 1000 \mathrm{~W} / \mathrm{kW}=330 \mathrm{kWh} / \mathrm{y}$

$\mathrm{AEC}=330 \mathrm{kWh} \times \$ 0.08 / \mathrm{kWh}=\$ 26.40 / \mathrm{y}$

AVEC $=\$ 26.50 \times 0.99=\$ 26.24$ (Same F4 used for both combinations)

TAVC $=\$ 2.30+\$ 2.60+\$ 26.24=\$ 31.14$

Annual-value net savings for higher efficiency combination $=\$ 35.44-\$ 31.14=\$ 4.30$

Conclusion: Higher efficiency lamp/ballast combination has annual-value net savings of $\$ 4.30$ per fixture compared to lower efficiency counterparts and is therefore the more cost-effective choice. 


\section{Replacement of Functioning Components}

In some cases, you may need to know whether replacing functioning components with more energyefficient counterparts to reduce energy consumption is a cost-effective investment. This section provides additional steps needed for this analysis, with examples. Since the simplified methodology is based on one-year time steps, the expected remaining life of the existing lamps and/or ballasts should be at least one year to use this methodology. You do not need an estimate of the remaining life beyond one year.

The methodology presented here does not predict the optimal time of replacement. If the replacement is not cost effective at the present time, you should reevaluate the replacement decision at a future time when electricity prices have increased relative to the prices of higher-efficiency lamps and ballasts.

Before the replacement analysis is conducted, use the methodology outlined in section 2 above to determine the most cost-effective lamp, ballast, or lamp/ballast combination for the lighting fixture of interest. If this "optimal" component (or combination of components) is different from the existing component(s), you should give further consideration to replacing the existing component(s) with the optimal component(s). Note that the installed cost of the new component(s) may vary significantly with the scale of the relamping effort, and that this should be reflected in the cost analysis.

After the most cost-effective replacement component(s) have been identified, compute the first-year electricity savings (in dollars) as the difference in annual energy costs (AEC) for the fixture with the existing components and the same fixture with the replacement component(s). If this difference is greater than the annualized installed cost of the replacement component(s) (using the corresponding annual-value factors from tables 1,2 , or 3 ), then install the replacement component(s) now. Otherwise delay the replacements until (1) the existing component(s) fail; (2) the cost of the replacement components decreases to the point where the replacements become cost effective; or (3) the cost of electricity increases to the point where the replacements become cost effective.

The following methodology and examples are for (A) lamp replacement only and (B) combined lamp/ballast replacement:

\section{A. Lamp replacement only:}

Calculate the annual-value lamp cost (AVLC) for the replacement lamps as shown in section 2 , step 2-A. Calculate the first-year electricity cost savings for the replacement lamps: AEC of fixture with existing lamps less AEC of fixture with replacement lamps, where AEC is calculated as shown in section 2, step 4 .

If first-year savings is greater than or equal to AVLC, the lamp replacement is cost effective now. If first-year savings is less than AVLC, the replacement is not cost effective now; repeat analysis in a later year when electricity prices have increased relative to high-efficiency lamp costs. 
Example (See section 3 for cost and operating assumptions):

Annual-value lamp cost $=(2 \times \$ 2.50+\$ 5.00) \times 0.23=\$ 2.30$ ( $\mathrm{F} 1$ based on 5-year lamp life) AEC of fixture with existing lamps $=\$ 31.20$

AEC of fixture with lower wattage lamps $=\$ 28.80$

First-year electricity savings $=\$ 31.20-\$ 28.80=\$ 2.40$

Net savings in first year $=\$ 2.40-\$ 2.30=\$ 0.10$ per fixture

Conclusion: replace lamps now

B. Combined Lamp/Ballast Replacement:

Calculate the annual-value cost of the replacement lamps (AVLC) and replacement ballast (AVBC) as shown in section 2, step 2-B and 2-C. Calculate the first-year electricity cost savings for the replacement lamp/ballast combination: AEC of fixture with existing lamp/ballast combination less AEC of fixture with replacement lamps and ballast, where AEC is calculated as shown in section 2, step 4 .

If the first-year savings is greater than or equal to AVLC $+A V B C$, the replacement is cost effective now. If the first-year savings is less than AVLC + AVBC, the replacement is not cost effective now; repeat analysis in later year after electricity prices have increased relative to high efficiency lamp component costs.

Example (See section 3 for cost and operating assumptions):

Annualized lamp cost $=(2 \times \$ 2.50+\$ 5.00) \times 0.23=\$ 2.30$ (F2 based on

20 -year ballast life and 5-year lamp life)

Annualized ballast cost $=(\$ 30.00+\$ 7.50-\$ 5.00) \times 0.08=\$ 2.60$

(F3 based on 20-year ballast life)

Total annualized lamp/ballast replacement cost $=\$ 4.90$

AEC of fixture with existing lamps and ballast $=\$ 31.20$

AEC of fixture with high-efficiency lamps and ballast $=\$ 26.40$

First-year electricity cost savings $=\$ 32.20-\$ 26.40=\$ 4.80$

Net savings in first year $=\$ 4.80-\$ 4.90=-\$ 0.10$ per fixture (i.e., net loss $=\$ 0.10$ )

Conclusion: Repiacement of functioning lamp/ballast combination at present time is not cost effective. 


\section{Appendix A. Computational methods for tables 1-4}

Table 1: Annual-value factors for lamps alone (F1)

$$
F 1=d \times(1+d)^{L L} /\left((1+d)^{L L}-1\right)
$$

where $d=$ discount rate $(0.046)$

and $L L=$ life of lamp

Table 2: Annual-value factors for lamps when evaluated with ballasts (F2)

$$
\begin{aligned}
& \mathrm{PV}=\sum_{i=1}^{n}(1+\mathrm{d})^{\mathrm{t}(\mathrm{i})} \\
& \mathrm{F} 2=\mathrm{PV} \times \mathrm{d} \times(1+\mathrm{d})^{\mathrm{LB}} /\left((1+\mathrm{d})^{\mathrm{LB}}-1\right)
\end{aligned}
$$

where PV = present-value factor for installed lamps costs

$d=$ discount rate $(0.046)$

$n=$ number of lamps installed over life of ballast (integer)

$t(i)=$ year of ith lamp installation $(t(1)=0, t(2)=L L$, etc.)

$L B=$ life of ballast

Table 3: Annual-value factors for ballasts (F3)

$$
F 3=d \times(1+d)^{L B} /\left((1+d)^{L B}-1\right)
$$

where $d=$ discount rate $(0.046)$

and $\mathrm{LB}=$ life of ballast

Table 4: Annual-value factors for electricity costs (F4)

$$
\begin{aligned}
& P V=\sum_{t=1}^{n} \frac{\text { Index }}{(1+d)^{\prime}} \\
& F 4=P V x d x(1+d)^{n} /\left((1+d)^{n}-1\right) \\
& \text { where } \mathrm{PV}=\text { present-value factor for electricity costs, } \\
& \text { Index },=\prod_{j=1}^{t}\left(1+e_{j}\right) \text {, } \\
& e_{j}=\text { DOE projected escalation rate for electricity prices in } \\
& \text { period } j(e(1)=\text { rate for 1992), for designated DOE } \\
& \text { region, commercial utility rates } \\
& d=\text { discount rate }(0.046) \text {, and } \\
& \mathrm{n}=\text { number of years (life) }
\end{aligned}
$$




\section{Appendix B. Limitations on the use of annual-value LCC for comparing investments with different lives}

Life-cycle cost (LCC) guidelines for Federal buildings, as detailed in NBS Handbook 135, require the use of LCC analysis for the economic evaluation of alternative energy conservation investments. In most cases, the present-value LCC (PVLCC) of alternative investments are compared directly to determine which has the lowest LCC. Comparison of PVLCCs requires that all alternatives be evaluated over the same study period. Comparison of the PVLCC of each alternative over its own life would essentially bias the analysis against alternatives with longer lives because more years of operating-related costs would be included. If alternatives have different lives, replacements and/or residual values must be used to adjust all alternatives to a common study period.

An alternative to present-value LCC analysis is annual-value LCC (AVLCC) analysis. A capital recovery factor is used to annualize the PVLCC. The AVLCC is a uniform annual cost, extending over the entire study period, which accounts for the time-value of money via the discount rate. Discounting uniform annual values back to the beginning of the study period and summing them yields the PVLCC.

With an important restriction, the AVLCC of alternative systems, each based on its own life, can be compared directly to determine the lowest LCC alternative. For example, the AVLCC of a lamp with a five-year life can be compared directly with the AVLCC of an alternative lamp with a six-year life, without having to adjust the investment costs of these two alternatives to a common time period using replacements or residual value. Implicit in this method is the assumption that each alternative would be replaced by a similar system at the same cost (in constant dollars).

The restriction on the use of AVLCC relates to increases in future costs over time. If annually recurring costs (e.g., annual energy costs) are the same from year to year in constant dollar terms, the annual-value factor for those costs will be the same (1.0), regardless of the life of the investment. Thus, if electricity costs were expected to be the same from year to year (in constant dollars), the annual-value factors in table 4 would all be 1.0 .

Since electricity costs are expected to change over time (based DOE forecasts), the annual-value factor for these costs will be different in each year, as is shown in table 4 . Using the annual-value factor for electricity prices corresponding to the life of each alternative biases the analysis against longer-lived alternatives when energy prices are expected to increase over time, since the factor is higher for those alternatives. The annual-value factor applied to the longer-lived alternative is higher because it reflects increases in electricity costs that occur only after the end of the life of the shorterlived alternative.

To eliminate this bias, use the same annual-value factor for electricity prices (F4) for all alternatives to be compared. In general, the life of the shortest-lived alternative is recommended as the basis for selecting F4. The use of a factor corresponding to the longer-lived alternative implies that the shortest-lived alternative will be replaced by a similar component at the end of its life. In fact, changes in technology, prices and institutional policy will likely result in a higher-efficiency replacement. 
The use of an identical annual-value factor for all alternatives only applies to the treatment of electricity prices in this methodology. The annual-value factors used with installed component costs (from tables 1-3) should be based on the expected life of the corresponding component. (In table 2 lamp replacement costs are assumed to remain approximately the same in constant dollars over the life of the ballast.) 

